\title{
ARBUSCULAR MYCORRHIZA IN SPECIES OF COMMELINIDAE (LILIOPSIDA) IN THE STATE OF PERNAMBUCO (BRAZIL) ${ }^{1}$
}

\author{
Gladstone Alves da Silva ${ }^{2}$ \\ Bartolomeu Acioli dos Santos ${ }^{2}$ \\ Marccus Vinícius Alves ${ }^{3}$ \\ Leonor Costa Maia ${ }^{2}$
}

Recebido em 17/11/99. Aceito em 15/02/01

\begin{abstract}
RESUMO - (Micorrizas arbusculares em espécies de Commelinidae (Liliopsida) no Estado de Pernambuco (Brasil). Micorrizas são associações simbióticas mutualísticas formadas entre fungos e raízes de plantas, sendo o principal benefício para a planta o aumento do aporte de nutrientes. Agronomicamente, a micorriza arbuscular (MA) é o tipo mais importante de micorrizas e apresenta-se distribuído na maioria dos ecossistemas. O objetivo deste trabalho foi estudar a condição micorrízica de espécies de Commelinidae que ocorrem no Estado de Pernambuco. Raízes dessas plantas, coletadas em 10 municípios, foram lavadas, clareadas em $\mathrm{KOH}$, coradas com azul de Tripano em lactoglicerol e observadas em microscópio para determinação da presença e identificação do tipo de micorriza formado. O percentual de colonização das raízes foi avaliado pelo método de interseção em placa quadriculada. Quarenta espécimens, representando 30 espécies, foram observados. Destes espécimens, 70\% estavam colonizados por fungos micorrízicos arbusculares (FMA). Em uma das famílias (Typhaceae) não foi encontrada a associação; em duas (Eriocaulaceae e Juncaceae) todos os espécimens apresentaram-se micorrizados e três (Commelinaceae, Cyperaceae e Poaceae) mostraram espécimens com ou sem FMA. Em algumas raízes foram observados outros fungos, além dos micorrízicos. Os resultados indicam que FMA estão amplamente distribuídos entre as espécies de Commelinidae em Pernambuco, sendo provavelmente importantes para o estabelecimento das mesmas nas áreas de coleta.
\end{abstract}

Palavras-chave - Cyperaceae, Eriocaulaceae, Poaceae, fungos micorrízicos, simbiose.

ABSTRACT - (Arbuscular mycorrhiza in species of Commelinidae (Liliopsida) in the State of Pernambuco (Brazil). Mycorrhiza are a mutualistic symbiosis between fungi and plant roots, the main benefit to the plant being increased nutrient uptake. The arbuscular is the most important kind of mycorrhiza for agriculture and it is widespread in occurrence and distribution in most ecosystems. The aim of this work was to study the mycorrhizal status of the species of Commelinidae that occur in the State of Pernambuco. Plant roots, collected in ten municipalities, were washed, cleared in $\mathrm{KOH}$, stained with Trypan blue in lactoglycerol and observed under a light microscope in order to assess presence and identification of the mycorrhizal type. Percentage of root colonization was evaluated by the

Auxílio PIBIC/CNPq ${ }^{1}$

Departamentos de Micologia ${ }^{2}$ e Botânica ${ }^{3}$ - Centro de Ciências Biológicas - Universidade Federal de Pernambuco, 50670-420, Recife - PE, Brasil. 
gridline intersect method. Forty specimens representing 30 species were observed. From these specimens, $70 \%$ were colonized by arbuscular mycorrhizal fungi (AMF). In one family (Typhaceae), mycorrhizal structures were not observed, in two of them (Eriocaulaceae and Juncaceae) all specimens showed the association, and three families (Commelinaceae, Cyperaceae and Poaceae) presented specimens with or without AMF. In some of the roots, other fungi were observed together with the AMF. The results indicate that AMF are widely distributed among species of Commelinidae in Pernambuco, being probably important for their establishment in the areas visited.

Key Words - Cyperaceae, Eriocaulaceae, Poaceae, mycorrhizal fungi, symbiosis.

\section{Introduction}

The mutualistic relationship of the mycorrhiza may have contributed to the evolution and survival of terrestrial plants and fungi and exists for over than 400 million years (Harley \& Smith, 1983). However, the ecological significance of this association only recently began to be recognized (Miller, 1987). Among the mycorrhiza, the arbuscular type presents high ecological and agronomical importance. They have little or no host specificity and are widespread in most ecosystems (Nicolson, 1967), from the forests to the deserts, and in tropical, temperate and arctic areas (Trappe, 1987). The mycorrhizal fungi are of common occurrence among phanerogams and constitute the rule and not the exception in nature (Harley, 1989; Siqueira, 1994). This wide distribution would indicate the important role of the arbuscular mycorrhizal fungi (AMF) in plant communities contributing for survival and growth of many plants (Harley, 1989; Colozzi-Filho \& Balota, 1994).

The mycorrhizal fungi have a prominent role in defining the ecological niches occupied by the plants and in determining plant communities composition (Francis \& Read, 1995). They also have the ability to induce a wide variety of growth responses in plant species that coexist in the same habitat (Sanders et al., 1996).

In mycorrhizal associations, the fungal mycelium extends outside the root and in this way the plant can, indirectly, explore a larger volume of soil (Sanders \& Tinker, 1971; Hayman \& Mosse, 1972). The mycorrhizal fungi receive photosynthates produced by the plant and, in exchange, increase the mineral and water uptake (Cooper \& Tinker, 1978); consequently, there is a general improvement of the plants nutritional state, what makes them more tolerant to stress of biotic or abiotic nature. Besides increasing the mineral uptake capacity of the plants, the mycorrhizal association may also supply a physical barrier against pathogens of the root system.

The Monocotyledoneae (Liliopsida) have fasciculated roots what may favour mycorrhizal formation. The presence or not of an arbuscular mycorrhizal association, or even the percentage of colonization, seems to be determined genetically (Janos, 1985; Alexander, 1989), and it is also influenced by physical and chemical environmental factors. Thus, a high diversity of factors such as soil, environment and management, age, species and variety of plants determine the formation of this symbiosis and the occurence of the AMF.

In a literature review of mycotrophic species, Trappe (1987) mentioned that from 49,900 Monocotyledoneae described, only 1,487 (3\%) had been analyzed; of this total, $21 \%$ did not reveal the association and $49 \%$ formed mycorrhiza of the arbuscular type. It was observed that no species of the orders Restionales and Hydatellales and less than 1\% of Eriocaulales had been examined with respect to their mycorrhizal condition. Among the Liliopsida, the order Typhales was the most examined (35\%); in the other orders of the subclass Commelinidae, the percentage of examined species varied from $1 \%$ in Juncales to $6 \%$ in Cyperales. The data 
presented by Trappe (1987), in spite of presenting only an initial idea of the reality, are important because they represent the union of several studies that looked for the mycorrhizal condition of species of Angiospermae. Studies are necessary to consider the role of the diversity of AMF, due to the lack of basic ecological and biological data on these fungi, which are of fundamental importance for the ecologists (Fitter, 1990). Sanders et al. (1996) consider that "for a given plant community we need to know how diverse is the AM fungal community, which plants are colonized by AM fungi, whether there is seasonality in the patterns of colonization, whether any specificity between plants and AM fungi occurs and what the effect of those AMF will be on plants and the ecosystem". Bellgard (1991) mentioned that before mycorrhiza can be used with success in the reforesting of degraded areas, it is necessary to know the mycorrhizal condition of the species of plants that occur naturally in the ecosystems without disturbance. In Brazil, few investigations have been made on frequency/distribution of AMF, but in general all of them mention the diversity of this group in the studied soils (Bononi \& Trufem, 1983; Trufem \& Bononi, 1985; Maia \& Trufem, 1990).

The objective of this work was to observe the mycorrhizal status of species of Commelinidae (Liliopsida) collected at different locations of the State of Pernambuco, and to verify the relationship between presence/absence and colonization degree in individuals of the same or other species, according to the collection place. The study of the mycorrhizal condition in species of Liliopsida in Brazil will contribute to the knowledge of the mycotrophic state of these plants and may indicate the role of AMF on their establishment in tropical areas.

\section{Material and methods}

\section{$\underline{\text { Collecting areas }}$}

The State of Pernambuco is located in the Northeast region of Brazil ( $7^{\circ} 15^{\prime} 45^{\prime \prime}-9^{\circ}$ $28^{\prime} 18^{\prime \prime} \mathrm{S}$ and $\left.34^{\circ} 48^{\prime} 33^{\prime \prime}-41^{\circ} 19^{\prime} 54^{\prime \prime} \mathrm{W}\right)$. Fifteen collections of specimens of Monocotyledoneae were made from August/ 95 to December/97 in ten municipal districts of the State embracing the zones of Tropical Rain Forest and "Caatinga", a stunted sparce forest which is divided in two subzones: Agreste (sub-humid area) and Sertão (semiarid area), which are geographically separated by a group of mountains that cross the State from north to south (Vasconcelos Sobrinho, 1949) (Tab. 1 and Fig. 1). The tropical forest zone presents a subdeciduous vegetation in the dry region (700-1000 mm of annual precipitation) and a non-deciduous broad leaf higrophyla vegetation in the humid region (Andrade-Lima, 1961, 1964; Silva Filho et al., 1998). In the "Caatinga" the vegetation, in general, consists of trees and shrubs which are deciduous during the dry season. Many of these plants are thorny, while some are succulent and leafless (Cactaceae and some Euphorbiaceae). There are also many Bromeliaceae and some herbs, mostly annual (Andrade-Lima, 1964).

\section{Root colonization}

Entire roots were collected, cleared with KOH (10\%) and stained with Trypan blue $(0,05 \%)$ (Phillips \& Hayman, 1970), with the lactophenol being changed to lactoglycerol. Naturally dark pigmented roots were cleared with $10 \%$ hydrogen peroxide for one hour before the staining with Trypan blue.

The percentage of root colonization was calculated by the gridline intersect method and, when the amount of roots was low, by the slide method (Giovanetti \& Mosse, 1980). 
Table 1 - Collecting places of specimens of Commelinidae, in the State of Pernambuco, Brasil.

\begin{tabular}{lll}
\hline ZONES* & SUBZONES* & COLLECTING PLACES (CYTIES) \\
\hline & & Cabo (Gurjaú Park) \\
TROPICAL FOREST & São Vicente Férrer \\
& & Igarassú (Charles Darwin Refugee) \\
& & São Lourenço da Mata (Tapacura Ecological Station) \\
& & Recife (Dois Irmãos Ecological Station) \\
"CAATINGA" & Bonito \\
\hline & AGRESTE & Caruaru (Brejo dos Cavalos) \\
& (SUB-HUMID AREA) & Alagoinha \\
\cline { 2 - 3 } & SERT $\tilde{O}$ (SEMI-ARID AREA) & Arcoverde \\
& & Serra Talhada \\
\hline
\end{tabular}

*Vasconcelos Sobrinho (1949)

Stained roots showing arbuscular mycorrhizal structures (arbuscles and vesicles) were selected for light microscope studies.

\section{Results}

Forty specimens, distributed in six families of Commelinidae were collected and studied. Among them, $28(70 \%)$ were colonized by AMF, with the colonization degree varying from $2 \%$, in Hypolytrum bullatum (Cyperaceae), to 68\% in Cyperus ligularis (Cyperaceae) (Tab. 2). Specimens of only one family did not present mycorrhizal association (Typhaceae), in two of them all specimens were symbiotic (Eriocaulaceae and Juncaceae), while three had specimens with and without AMF (Commelinaceae, Cyperaceae and Poaceae).

The mycorrhizal structures present in the roots included hyphae, vesicles and arbuscles, the latter being difficult of observing. The hyphae were hyaline and well ramified. In some roots as those of Becquerelia cymosa, hyphal coils were also observed.
Variation on presence/absence and intensity of mycorrhizal colonization at the species and genus levels were observed in some cases. In Cyperus (Cyperaceae), variation in colonization occurred among specimens collected in different phytogeographic zones. In Commelina (Commelinaceae) there was difference in the level of colonization among plants collected from different points of the same place and also regarding presence-absence of mycorrhizal association on different collecting places. Presence/absence of AMF colonization varied among the specimens of Scleria and Rhynchospora (Cyperaceae). Data related to occurrence of species for each analyzed family were compared with the number of species and specimens as well as with the number of those forming mycorrhiza (Tab. 3).

Concerning the species collected in more than one occasion, three different variation patterns were observed in the formation or not of the mycorrhizal association and/or of the colonization in function of the host plants and environment of origin: a) species that were collected in different points of a same 
Table 2 - Mycorrhizal colonization of specimens of Commelinidae collected in several areas of the State of Pernambuco, Brazil.

\begin{tabular}{|c|c|c|}
\hline FAMILIES/SPECIES & COLLECTING PLACES & $\begin{array}{c}\text { COLONIZATION } \\
(\%)\end{array}$ \\
\hline \multicolumn{3}{|l|}{ COMMELINACEAE } \\
\hline Commelina rufipens Seub.* & Cabo & 0 \\
\hline Commelina rufipens Seub. * & São Vicente Férrer & 4 and 39 \\
\hline Commelina diffusa Burm. f. * & São Vicente Férrer & 0 \\
\hline \multicolumn{3}{|l|}{ CYPERACEAE } \\
\hline Becquerelia cymosa Brong. * & São Vicente Férrer & $\ddagger$ \\
\hline Becquerelia cymosa Brong. * & Caruaru & 50 \\
\hline Cyperus haspan L. & São Vicente Férrer & 0 \\
\hline Cyperus ligularis Lam.* & Recife & 68 \\
\hline Cyperus luzulae (L.) Retz. * & São Vicente Férrer & 0 \\
\hline Cyperus odoratus L. & Serra Talhada & 47 \\
\hline Cyperus pohlii (Nees) Steud. * & Arcoverde & 0 \\
\hline Cyperus rotundus L. * & Cabo & 0 \\
\hline Cyperus squarrosus L. & Alagoinha & 4 \\
\hline Cyperus surinamensis Rottb. * & Alagoinha & 31 and 43 \\
\hline Eleocharis geniculata (L.) Roem. \& Schult. * & Recife & 24 \\
\hline Hypolytrum bullatum C.B. Clarke & São Vicente Férrer & 2 \\
\hline Pleurostachys puberulenta Boeck. * & Caruaru & 32 \\
\hline Rhynchospora cephalotes (L.) Vahl & Igarassú & 29 \\
\hline Rhynchospora cephalotes (L.) Vahl & São Lourenço da Mata & 0 \\
\hline Rhynchospora ciliata Kükenth. * & Cabo & 0 \\
\hline Rhynchospora corymbosa (L.) Britton * & Bonito & 15 \\
\hline Rhynchospora pubera (Vahl) Boeck. & São Vicente Férrer & 43 \\
\hline Scleria latifolia Sw. & São Vicente Férrer & 29 \\
\hline Scleria latifolia Sw. * & Caruaru & 0 \\
\hline $\begin{array}{l}\text { Scleria melaleuca } \text { Reichb. } \\
\text { ERIOCAULACEAE }\end{array}$ & Cabo & 0 and 30 \\
\hline $\begin{array}{l}\text { Tonina fluviatilis Aubl. } \\
\text { JUNCACEAE }\end{array}$ & Recife & 20 \\
\hline Juncus microcephalus Kunth & Caruaru & 37 \\
\hline \multicolumn{3}{|l|}{ POACEAE } \\
\hline Brachiaria sp. & Cabo & 16 \\
\hline Echinochloa colona (L.) Link & Alagoinha & 22 \\
\hline Ichnanthus aff. Petiolatus (Nees) Doell. * & Recife & 51 \\
\hline Lasiacis ligulata Hitchc. \& Chase * & Caruaru & 37 and 48 \\
\hline Leptochloa virgata (L.) P. Beauv. & Caruaru & 23 \\
\hline Olyra latifolia L. * & Cabo & 35 \\
\hline Pharus latifolius L. * & Cabo & 0,31 and 42 \\
\hline TYPHACEAE & & \\
\hline Typha domingensis Pers & Arcoverde & 0 \\
\hline
\end{tabular}

$(*)=$ Presence of others fungi. $(\ddagger)=$ Presence of pathogenic fungi masked the colonization by AMF.

place and showed some variation in the percentage of mycorrhizal colonization (Cyperus surinamensis, Lasiacis ligulata and Pharus latifolius) and/or presence/absence of association with AMF (Pharus latifolius and Scleria melaleuca); b) species that occurred at different places and showed variation with relation to presence/absence of mycorrhiza (Rhynchospora cephalotes and Scleria latifolia); c) species that showed variation in the colonization degree when collected in different points of the same place and absence of AMF in other collecting place (Commelina rufipens).

In 22 specimens (out of 40) other fungi, probably pathogens, were present independently of presence of AMF. In Becquerelia cymosa the presence of other fungi impaired the evaluation of the degree of colonization by AMF. 
Table 3 - Families of Commelinidae in the State of Pernambuco: number of species, number of specimens and species observed and number of species with arbuscular mycorrhizal association.

\begin{tabular}{|c|c|c|c|c|}
\hline Families & $\mathrm{N}^{0}$ of species in Pernambuco & $\mathrm{N}^{\circ}$ of observed specimens & $\mathbf{N}^{\circ}$ of observed species & Mycorrhizal Species \\
\hline COMMELINACEAE & $20^{1}$ & 4 & 2 & 1 \\
\hline CYPERACEAE & $128^{2}$ & 23 & 18 & 13 \\
\hline ERIOCAULACEAE & $10^{1}$ & 1 & 1 & 1 \\
\hline JUNCACEAE & $1^{1}$ & 1 & 1 & 1 \\
\hline POACEAE & $90^{1}$ & 10 & 7 & 7 \\
\hline TYPHACEAE & $1^{1}$ & 1 & 1 & 0 \\
\hline
\end{tabular}

1 - Alves (personal communication); 2 - Luceño et al. (1997).

\section{Discussion}

The data indicated that the arbuscular is the dominant type of mycorrhiza in species of Commelinidae in different areas of the State of Pernambuco. Koske et al. (1992) mentioned that from 147 species they observed in Hawaii, 122 were colonized and from those, $98 \%$ formed arbuscular mycorrhiza. The authors considered that the incidence of mycotrophy in endemic species of Hawaii $(90.3 \%)$ is more significant than in continental species $(71.9 \%)$ and suggested that AMF and species of plants obligatorily mycorrhizal were present in the Hawaiian islands during the first stages of development of the angiospermic flora. After observing the mycorrhizal colonization in trees of a tropical forest in Ecuador, Lunt \& Hedger (1996) suggested that the colonization of plants by AMF is dominant in this type of forest. They studied 23 species, and from these, 15 were colonized by AMF. Observing roots in the amazon forest, St. John (1980) observed that about $22 \%$ of the total roots examined, were not colonized by AMF. Singer \& Araújo (1979) in a work also done in the Amazonia, compared different forests and verified that in the "campinarana", a forest on podzolic soil of white sand, the dominant trees are ectotrophically mycorrhizal, while in the primary forest of "terra firme", most of the trees did not have ectomycorrhiza. After observations in a tropical forest in Pernambuco, Rose \& Paranka (1987) mentioned the occurrence of a high colonization index (88 to $90 \%$ ) by AMF in roots present in the litter, while ectomycorrhizas were not found. The collections made in Pernambuco were predominantly in forest areas, even those in the semi-arid areas, because the plants were developing in a high altitute land where a similar tropical forest developed forming an "oasis" in the area. Considering that only arbuscular mycorrhiza were detected, the dominance of AMF in tropical forest areas was confirmed.

The variations in some species with relation to the colonization degree and presence/absence of AMF in the same or in different collecting places, seems to indicate, as pointed out by Alexander (1989), that environmental factors linked to the host, influence the presence and mycorrhizal colonization level. St. John (1980) observed that at both, genus and family levels, colonization was constant in some or varied in others. Trufem \& Bononi (1985) suggested four patterns for AMF colonization based on host and season of the year. Here, distribution patterns were related with presence/absence and colonization level of arbuscular mycorrhizal fungi in the same or in different areas. This represents a tentative to better understand the distribution of AMF, and other studies are in progress to corroborate what has been observed up to now.

Commelinaceae - From the four observed plants, two were not colonized by AMF. The presence of such fungi in plants of this family, considered for some authors (Harley \& Smith, 1983; Silveira, 1992) as "nonmycorrhizal", was also described by Taber \& Strong (1982) 


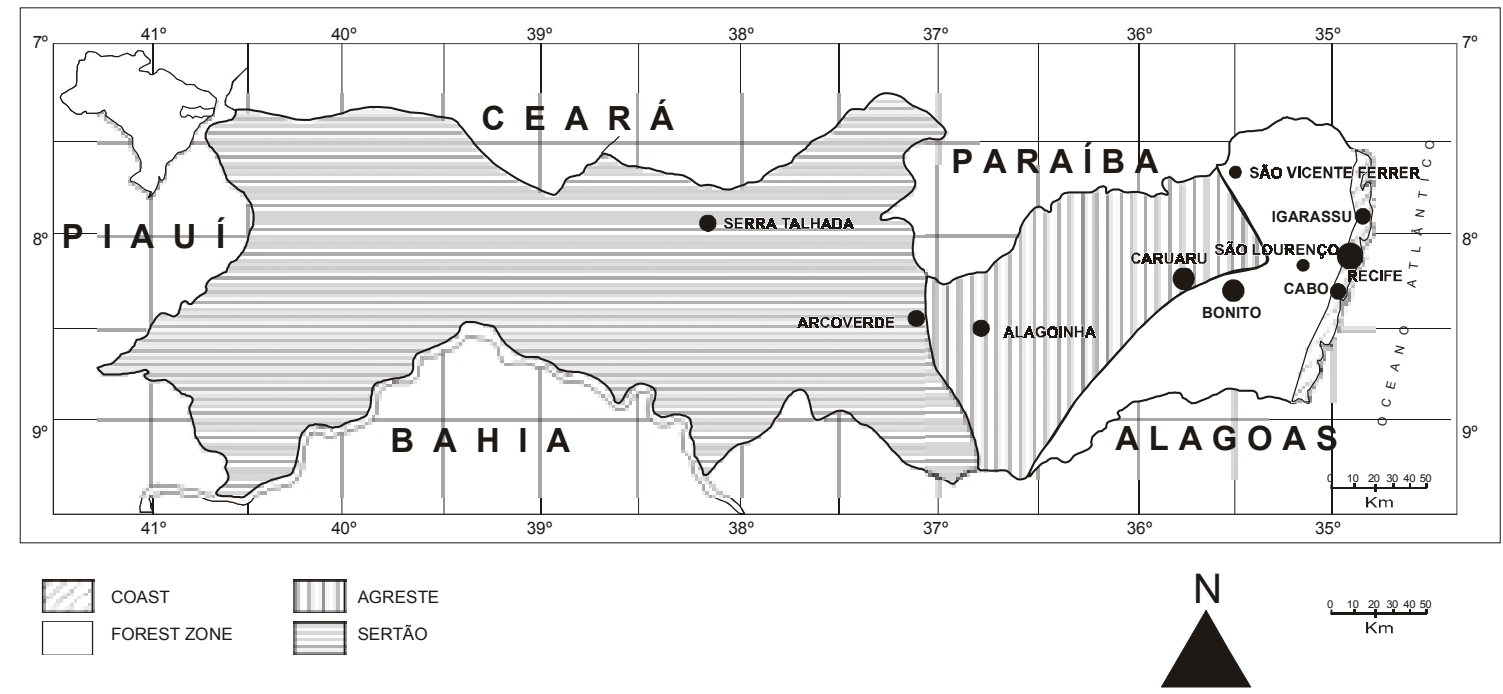

Figure 1. Collecting places in the State of Pernambuco.

who observed dense colonization in roots of Tradescantia virginiana $\mathrm{L}$. collected in Alabama, USA. These authors also mentioned that hypha of AMF were found in the xylem of the roots; however, it is known that AMF structures do not invade the central cylinder. Thus, possibly the hyphae in the xylem belonged to nonmycorrhizal fungi. In the specimens of Commelina rufipens, the mycorrhizal structures were in the cortical area, as characteristic of the association. Commelina benghalensis L., C. caerulea Salisb. and Tradescantia purpurascens Shau. were referred as mycorrhizal by Tester et al. (1987).

Cyperaceae - Harley \& Smith (1983) and Silveira (1992) mentioned the family Cyperaceae as "nonmycotrophic". Bagyaraj et al. (1979) observed that Cyperus eleusinoides Kunth (aquatic macrophyta) was not colonized by mycorrhizal fungi; however, they considered that the establishment of the association is not favoured in plants of aquatic habitat. On studies performed in different areas, Koske \& Halvorson (1981), Malloch \& Malloch (1982), Brundrett \& Kendrick
(1988) and Louis (1990) did not find colonization in specimens of this group. However, Kobresia myosuroides (Vill.) Fiori \& Paol. was found forming ectomycorrhiza in an arctic area (Kohn \& Stasovski, 1990). Bledsoe et al. (1990) considered that AMF are rare in the high arctic, and probably have small or no importance in improving growth and nutrition of species that live in such environments.

Presence of arbuscular mycorrhiza in specimens of Cyperaceae, as shown here, confirm observations of other authors (Sondergaard \& Laegaard, 1977; Harley \& Harley, 1987; Tester et al., 1987; Bellgard, 1991; Koske et al., 1992; Bellgard et al., 1994; Miller et al., 1999). Miller et al. (1999) suggested that, in the genus Carex, taxonomic and environmental factors have influence in the mycorrhizal status. They found that some species appear to be typically mycorrhizal, others are usually nonmycorrhizal and other group have a mycorrhizal status that appear to depend upon the environment. Based on these observations, Cyperaceae should not be in the nonmycorrhizal group, since that strong evidences of the association in several species of this family do exist. 
Eriocaulaceae - According to Trappe (1987) only one species of this family was examined regarding its mycotrophic status and did not show colonization. It is possible that the lack of information about mycotrophy of plant species in Brazil is responsible for that, considering that the center of diversity of this group is located in the "Cadeia of Espinhaço", a large chain of mountains that extends from Bahia to Minas Gerais and where several cases of endemism are known (Alves, personal communication). In Tonina fluviatilis, $20 \%$ of the roots were colonized by AMF. Apparently, this is the first report of mycorrhizal association in roots of Eriocaulaceae species.

Juncaceae - Trappe (1987) mentioned that 42 species $(1 \%)$ of the order Juncales were observed regarding the mycotrophic state, and some of these were colonized by AMF. Harley \& Smith (1983) and Silveira (1992) considered this family as "nonmycorrhizal." Kohn \& Stasovski (1990) and Bledsoe et al. (1990) examining plants in a Canadian arctic area observed that none of the species of Juncaceae formed mycorrhizae. However, Juncus microcephalus, examined in this work, was colonized by AMF; other authors also mentioned the presence of mycorrhizal association in species of this family. Working with Angiosperms of Hawaii, Koske et al. (1992) observed colonization of two species of Juncaceae (Juncus planifolius R. Br. and Luzula hawaiiensis Buechenau var. hawaiiensis) by AMF. During a literature review about the mycorrhizal condition of the British flora, Harley \& Harley (1987) found AMF in $63 \%$ of the species of Juncaceae. Tester et al. (1987) mentioned some species of this family forming mycorrhizae (Juncus articulatus L., J. novaezelandiae Hook. F., J. planifolius R. Br., J. squarrosus L., Luzula pilosa (L.) Willd, L. campestris (L.) DC. and L. spicata (L.) DC.). Based on these data it is suggested that Juncaceae should be placed among the families with mycorrhizal and nonmycorrhizal species.

Poaceae - AMF were present in nine out of ten plants studied. Louis (1990) investigated the mycorrhizal status of plants that colonized an area with reclaimed land by the deposition of marine sand in the coast of Singapura. After five years it was observed that no Aizoaceae, Cyperaceae and Verbenaceae had mycorrhizal colonization, while all "grasses" (Poaceae) were colonized by AMF. Harley \& Harley (1987) mentioned that $60 \%$ of 173 Poaceae species of the British flora were observed for mycorrhizal association and from this total, $87 \%$ presented AMF. In Hawaii, Koske et al. (1992) studied nine Poaceae species and all of them were colonized by AMF. Giovanetti \& Nicolson (1983) studied three species of this family in some Italy sand dunes and all of them were associated with mycorrhizal fungi. Nicolson (1960), Miller (1979), Reeves et al. (1979), Koske \& Halvorson (1981), Bethlenfalvay et al. (1984), Berch et al. (1988) and Hopkins (1987) also described formation of mycorrhiza in most of the Poaceae specimens that they studied. Conversely, some papers show specimens of Poaceae without mycorrhizal association. Kohn \& Stasovski (1990) did not find mycorrhizae in Festuca brachyphylla Schult. and Poa arctic R. Br. subsp. caespitaus (Simm.). According to Bagyaraj et al. (1979) Echinochloa colonum (L.) Link and Panicum psilopodium Trin. did not show mycorrhizal colonization. Only one of the specimens of Poaceae here studied was more than $50 \%$ colonized by AMF. Thompson \& Wildermuth (1989) observed that in general the grasses have low percentage of colonization, although the total weight of colonized roots is considerable and should be as effective as in leguminosae. Wilson \& Hartnett (1998) inoculated AMF in some species of praire tallgrass and mentioned that 
responses to mycorrhizal colonization of the perennial grass species tested (all Poaceae) indicated that warm- and cool-season phenology appears to be a critical factor in determining mycorrhizal responsiveness in these species. They observed that only one from 16 species of perennial warm-season grasses showed no significant increase in dry mass in response to colonization by AMF; however, in only two from the 14 species of the perennial cool-season grasses, the dry mass was significantly improved as compared to the nonmycorrhizal controls. Apparently, formation of mycorrhizal association is important for this group of plants since most of the papers on this subject mention formation of mycorrhiza in Poaceae.

Typhaceae - Typha domingensis was not colonized by mycorrhizal fungi; our observations confirmed those of Bagyaraj et al. (1979) who did not find mycorrhiza on Typha augusta Chaub \& Boy. However, Typha angustifolia $\mathrm{L}$. was found forming arbuscular mycorrhiza (Harley \& Harley, 1987).

Other fungi (nonmycorrhizal) were also found in most of the studied specimens of Commelinaceae, Cyperaceae and Poaceae. The presence of other fungi, together with AMF into the roots, has being described by some authors (Berch et al., 1988; Kohn \& Stasovski, 1990). Conversely, some researchers mention that formation of mycorrhiza inhibit the presence of other fungi. Thompson \& Wildermuth (1989) worked with 37 species of cultivated plants used or not as pasture, in soils with Bipolaris sorokiniana (Sacc.) Shoem., a well-known phytopathogenic fungus, and verified that all plants, except species of Cruciferae and a Leguminosae, showed mycorrhizal colonization that varied from $60 \%$ to $98 \%$. Apparently, in this case the presence of AMF was antagonistic to the infection by $B$. sorokiniana.
From our results, it is possible to suggest that arbuscular mycorrhizal fungi are widely disseminated among the species of Commelinidae in Pernambuco, being probably important for their establishment throughout the areas studied.

\section{Acknowledgements}

We are gratefull to Dr. James Kimbrough for reading the manuscript and making valuable sugestions. Thanks are due to the Conselho Nacional de Desenvolvimento Científico e Tecnológico (CNPq) for financial support.

\section{References}

Alexander, I. J. 1989. Mycorrhizas in tropical forests. Pp. 169-188. In: J. Proctor (Ed.), Mineral nutrients in tropical forest and savannah ecosystems. Blackwell, Oxford.

Andrade-Lima, D. 1961. Tipos de florestas de Pernambuco. Anais, Associação de Geógrafos do Brasil 12: 69-85.

Andrade-Lima, D. 1964. Contribution to the study of the flora of Pernambuco, Brazil. M.Sc. Thesis, New York State University, New York. 154p.

Bagyaraj, D. J.; Manjunath, A. \& Patil, R. B. 1979. Occurrence of vesicular-arbuscular mycorrhizas in some tropical aquatic plants. Transactions of the British Mycological Society 72: 164-167.

Bellgard, S. E. 1991. Mycorrhizal associations of plant species in Hawkesbury Sandstone vegetation. Australian Journal of Botany 39: 357-364.

Bellgard, S. E.; Whelan, R. J. \& Muston, R. M. 1994. The impact of wildfire on vesicular-arbuscular mycorrhizal fungi and their potential to influence the re-establishment of post-fire plant communities. Mycorrhiza 4: 139-146.

Berch, M. S.; Gamiet, S. \& Deom, E. 1988. Mycorrhizal status of some plants of southwestern British Columbia. Canadian Journal of Botany 66: 1924-1928.

Bethlenfalvay, G. J.; Dakessian, S. \& Pacovsky, R. S. 1984. Mycorrhizae in a southern California desert: ecological implications. Canadian 
Journal of Botany 62: 519-524.

Bledsoe, C.; Klein, P. \& Bliss, L. C. 1990. A survey of mycorrhizal plants on truelone Lowland, Devon Island Northwest territories, Canada. Canadian Journal of Botany 68: 1848-1856.

Bononi, V. L. R. \& Trufem, S. F. B. 1983. Endomicorrizas vesículo-arbusculares do cerrado da Reserva Biológica de Moji-Guaçú, SP, Brasil. Rickia 10: 55-84.

Brundrett, M. C. \& Kendrick, B. 1988. The mycorrhizal status, root anatomy, and phenology of plants in a sugar maple forest. Canadian Journal of Botany 66: 1153-1173.

Colozzi-Filho, A. \& Balota, E. L. 1994. Micorrizas arbusculares. Pp. 383-418. In: M. Hungria \& R. S. Araújo (Eds.), Manual de métodos empregados em estudos de microbiologia agrícola. EMBRAPA-SPI-CNPAF-CNPSO, Brasília.

Cooper, K. M. \& Tinker, P. B. 1978. Translocation and transfer of nutrients in vesicular-arbuscular mycorrhizas. II. Uptake and translocation of phosphorus, zinc and sulphur. New Phytologist 81: $43-52$.

Fitter, A. H. 1990. The role and ecological significance of vesicular-arbuscular mycorrhizas in temperate ecosystem. Agriculture, Ecosystems and Environment 29: 137-151.

Francis, R. \& Read, D. J. 1995. Mutualism and antagonism in the mycorrhizal symbiosis, with special reference to impacts on plant community structure. Canadian Journal of Botany 73 (Supp.1): 1301- 1309.

Giovanetti, M. \& Mosse, B. 1980. An evaluation of techniques for measuring vesicular arbuscular mycorrhizal infection in roots. New Phytologist 84: 489-500.

Giovannetti, M. \& Nicolson, T. H. 1983. Vesiculararbuscular mycorrhizas in Italian sand dunes. Transactions of the British Mycological Society 80: 552-557.

Harley, J. L. 1989. The significance of mycorrhiza. Mycological Research 92: 129-139.

Harley \& Harley. 1987. A cheklist of the status mycorrhizal of the British flora. New Phytologist (Suppl.) 105: 1-102.

Harley, J. L. \& Smith, S. E. 1983. Mycorrhizal Symbiosis. Academic Press, London. 483p.

Hayman, D. S. \& Mosse, B. 1972. Plant growth responses to vesicular-arbuscular mycorrhiza. III. Increased uptake of labile phosphorus from soil. New Phytologist 71: 41-47.
Hopkins, N. A. 1987. Mycorrhizae in a California serpentine grassland community. Canadian Journal of Botany 65: 484-487.

Janos, D. P. 1985. Mycorrhizal fungi: agents or symptoms of tropical community composition? Pp. 98-103. In: R. Molina (Ed.) 6' ${ }^{\text {th }}$ North American Conference on Mycorrhizae, Bend, Oregon, USA. June 25-29, 1984. Forest Research Laboratory, Oregon.

Kohn, L. M. \& Stasovski, E. 1990. The mycorrhizal status of plants at Alexandra Fiord, Ellesmere Island, Canada, a high arctic site. Mycologia 82: 23-35.

Koske, R. E. \& Halvorson, W. L. 1981. Ecological studies of vesicular-arbuscular mycorrhizae in a barrier sand dune. Canadian Journal of Botany 59: 1413-1422.

Koske, R. E.; Gemma, J. N. \& Flynn, T. 1992. Mycorrhizae in Hawaiian angiosperms: a survey with implications for the origin of the native flora. American Journal of Botany 79: 853-862.

Louis, I. 1990. A mycorrhizal survey of plant species colonizing coastal reclaimed land in Singapore. Mycologia 82: 772-778.

Luceño, M.; Alves, M. V. \& Mendes, A. P. 1997. Catálogo florístico y claves de identificación de las ciperáceas de los Estados de Paraíba y Pernambuco (nordeste de Brasil). Anales del Jardím Botánico de Madrid 55: 67-100.

Lunt, P. H. \& Hedger, J. N. 1996. A survey of mycorrhyzal infection of trees in the terra firme rainforest, Cuyabeno, Ecuador. Mycologist 10: 161-165.

Maia, L. C. \& Trufem, S. F. B. 1990. Fungos micorrízicos vesículo-arbusculares em solos cultivados no Estado de Pernambuco, Brasil. Revista Brasileira de Botânica 13: 89-95.

Malloch, D. \& Malloch, B. 1982. The mycorrhizal status of boreal plants: additional species from northeastern Ontario. Canadian Journal of Botany 60: 1035-1040.

Miller, R. M. 1979. Some occurrences of vesiculararbuscular mycorrhiza in natural and disturbed ecosystems of the Red Desert. Canadian Journal of Botany 57: 619-623.

Miller, R. M. 1987. Mycorrhizae and succession. Pp. 205-220. In: W. R. Jordan III; M. E. Gilpin \& J. D. Aber (Eds.), Restoration Ecology: A Synthetic Approach to Ecological Research. Cambridge University Press, Cambridge.

Miller, R. M.; Smith, C. I.; Jastrow, J. D. \& Bever, J. D. 1999. Mycorrhizal status of the genus Carex 
(Cyperaceae). American Journal of Botany 86: 547-551.

Nicolson, T. H. 1960. Mycorrhiza in the Gramineae. II. Development in different habitats, particularly sand dunes. Transactions of the British Mycological Society 43: 132-145.

Nicolson, T. H. 1967. Vesicular-arbuscular mycorrhiza - a universal plant symbiosis. Science Progress 55: 561-581.

Phillips, J. M. \& Hayman, D. S. 1970. Improved procedures for clearing roots and staining parasitic and vesicular arbuscular mycorrhizal fungi for rapid assessment of infection. Transactions of the British Mycological Society 55: $158-161$.

Reeves, B. F.; Wagner, D.; Moorman, T. \& Kiel, J. 1979. The role of endomycorrhizae in revegetation practices in the semi-arid West. I. A comparison of incidence of mycorrhizae in severely disturbed vs. natural environments. American Journal of Botany 66: 6-13.

Rose, S. L. \& Paranka, J. E. 1987. The location of roots and mycorrhizae in tropical forest litter. Pp. 165. In: D. M. Sylvia; L. L. Hung \& J. H. Graham (Eds.) Practical applications and research priorities. Proceedings of the $7^{\text {th }}$ North American Conference on Mycorrhizae, Gainesville, Fl. May 3-8, 1987. IFAS, Gainesville.

Sanders, I. R.; Clapp, J. P. \& Wiemken, A. 1996. The genetic diversity of arbuscular mycorrhizal fungi in natural ecosystems - a key to understanding the ecology and functionig of the mycorrhizal symbiosis. New Phytologist 133: 123-134.

Sanders, F. E. \& Tinker, P. B. 1971. Mechanism of absorption of phosphate from soil by Endogone mycorrhizas. Nature 233: 278-279.

Silva Filho, A. A.; Toniolo, E. R.; Gabínio, M. \& Oliveira, S. F. S. 1998. Mapeamento da cobertura florestal nativa lenhosa do estado de Pernambuco (Documento de Campo FAO $\mathrm{n}^{\circ}$ 17) PNUD/FAO/IBAMA/ Governo de Pernambuco, Recife. 32p.

Silveira, A. P. D. 1992. Micorrizas. Pp. 257-282. In: E. J. B. N. Cardoso; S. M. Tsai \& M. C. P. Neves (Eds.) Microbiologia do solo. Sociedade Brasileira de Ciência do Solo, Campinas.

Singer, R. \& Araújo, I. 1979. Litter decomposition and ectomycorrhiza in Amazonian forests. Acta Amazonica 9: 25-41.

Siqueira, J. O. 1994. Micorrizas arbusculares. Pp. 151194. In: R. S. Araújo \& M. Hungria (Ed.) Microorganismos de importância agrícola.
EMBRAPA/CNPAF Série Doc., ${ }^{\circ}$ 44, Brasilia.

Sondergaard, M. \& Laegaard, S. 1977. Vesiculararbuscular mycorrhiza in some aquatic vascular plants. Nature 268: 232-233.

St. John, T. V. 1980. A survey of mycorrhizal infection in an amazonian rain forest. Acta Amazonica 10: 527-533.

Taber, R. A. \& Strong, M. E. 1982. Vesiculararbuscular mycorrhiza in roots and xylem of Tradescantia. Mycologia 74: 152-155.

Tester, M.; Smith, S. E. \& Smith, F. A. B. 1987. The phenomenon of "nonmycorrhizal" plants. Canadian Journal of Botany 65: 419-431.

Thompson, J. P. \& Wildermuth, G. B. 1989. Colonization of crop and pasture species with vesicular - arbuscular mycorrhizal fungi and a negative correlation with root infection by Bipolaris sorokiniana. Canadian Journal of Botany 67: 687-693.

Trappe, J. M. 1987. Phylogenetic and ecological aspects of mycotrophy in the Angiosperms from an evolutionary standpoint. Pp. 5-25. In: G. R. Safir (Ed.) Ecophysiology of VA mycorrhizal plants. CRC Press, Boca Raton.

Trufem, S. F. B. \& Bononi, V. L. R. 1985. Micorrizas vesículo-arbusculares de culturas introduzidas em áreas de cerrado. Rickia 12: 165-187.

Vasconcelos Sobrinho, J. 1949. As regiões naturais de Pernambuco, o meio e a civilização. Freitas Bastos, Rio de Janeiro. 219p.

Wilson, G. W. T. \& Hartnett, D. C. 1998. Interspecific variation in plant responses to mycorrhizal colonization in tallgrass prairie. American Journal of Botany 85: 1732-1738. 